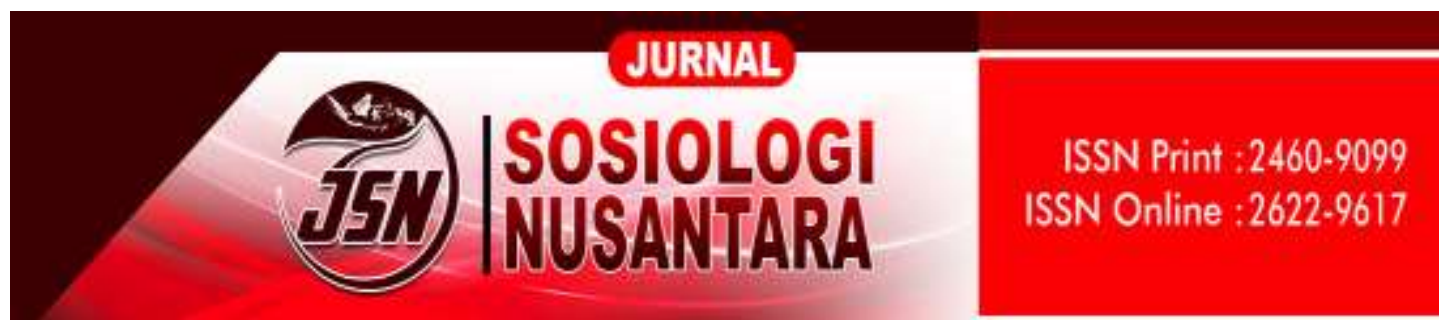

https://ejournal.unib.ac.id/index.php/jsn

DOI ://doi.org/10.33369/jsn.7.1.17-36

\title{
POTRET SI FAHMI: SISWA KAYA YANG GAGAL BERPRESTASI
}

\section{FAHMI'S POTRAIT: A RICH STUDENT FAILING HIS SCHOOL}

\author{
Sintia Margani ${ }^{1}$, Nanang Martono ${ }^{2}$, Elis Puspitasari ${ }^{3}$ \\ sintia.margani@mhs.unsoed.ac.id, nanang.martono@unsoed.ac.id, \\ elis.puspitasari@unsoed.ac.id \\ 1,2,3 Program Studi Sosiologi Universitas Jenderal Soedirman, Purwokerto
}

\begin{abstract}
Abstrak
Artikel ini menggambarkan habitus siswa kelas atas yang gagal mengukir prestasi di sekolah. Siswa kelas atas gagal berprestasi karena tidak memiliki habitus berprestasi seperti belajar dengan konsentrasi, mendengarkan guru, aktif bertanya dan menjawab, membaca dan membuat catatan, membuat jadwal belajar dan pelaksanaannya, mengatur waktu belajar, mengulang pelajaran, mengerjakan PR serta menghafal pelajaran. Penelitian ini dilakukan dengan metode life history yang dilakukan di salah satu SMA di Kota Cilacap. Penentuan informan dilakukan dengan menggunakan purposive sampling, yaitu siswa kaya yang gagal berprestasi. Hasil penelitian menunjukkan bahwa kepemilikan berbagai "modal" seperti modal ekonomi (berasal dari keluarga kelas atas), budaya (memiliki banyak pengalaman sosial), sosial (jaringan pertemanan) dan simbolik (memiliki banyak fasilitas belajar) tidak membuat siswa kaya dapat berprestasi. Salah satu contohnya adalah Fahmi. Ia gagal berprestasi karena memiliki habitus malas, gemar menyontek, senang bermain, serta memiliki kebiasaan membolos. Habitus tersebut terbentuk melalui proses sosialisasi habitus yang terjadi di lingkungan keluarga, pertemanan dan sekolah. Habitus malas belajar berkembang karena lingkungan keluarga yang tidak membiasakan Fahmi untuk belajar membaca dan menulis sejak kecil. Lingkungan sekolah juga mengembangkan habitus malas belajar melalui cara mengajar guru yang membiasakan siswanya untuk menghapal soal. Lingkungan pertemanan bahkan berperan besar menumbuhkan semua habitus yang melekat pada Fahmi. Jadi, kegagalan berprestasi yang dialami Fahmi disebabkan kegagalan sosialisasi habitus berprestasi di lingkungan keluarga, pertemanan dan sekolah meskipun ia memiliki banyak modal yang dapat digunakan untuk mendukung capaian belajarnya.
\end{abstract}

Kata Kunci: Habitus, Modal, Prestasi, Siswa Kaya 


\begin{abstract}
This study portrays the habitus of upper-class students who face school failure. The upper-class students extensively fail due to a lack of habitus of being achiever, such as paying attention while studying, listening to the teacher, actively engaging in question section, reading and make notes, arranging time table, finishing homework, and so on. This research is determined by the life history method undertaken at one of the high schools in Cilacap. The researcher uses purposive sampling for accessing a particular subset of people, as all the upper-class students with the school failure are selected. The result indicates that the ownership of capital such as economic (ownership of internet networks, smartphones and laptops), cultural (weekend experience), social (network of friend) and symbolic capital (live in housing) does not exacerbate the condition of high school achievement. For example, Fahmi. His tend to fail because he have a habitus such as procrastinating, cheating, playing most of the time and skipping class. The habitus is gradually affirmed through the process of socialization around family, peer group, and school. The habitus of procrastinating is formed due to a lack of parental habitus to get Fahmi to read and write since childhood. Other than that, schools are also the reason for strengthening the portrait of the habitus through the studying process. The process is mostly delivered to memorize the materials. The peer group also plays a huge role where the habitus has adhered to Fahmi. So, the failure to achieve that is experienced by Fahmi is caused by the failure to socialize the achievement habitus in the family, peer group and school environment even though he had a lot of capital that could be used to support his learning outcomes.
\end{abstract}

Keywords: Habitus, Capital, School Achievement, Upper-Class Student

\title{
PENDAHULUAN
}

Secara sosiologis, siswa di sekolah dapat diklasifikasikan menurut latar belakang sosial dan kemampuan akademiknya (Idi and Safarina, 2016). Jika kedua dasar klasifikasi tersebut digunakan untuk mengelompokkan keberagaman siswa, maka akan muncul empat kelompok siswa, yaitu: siswa kaya-pintar, siswa kayabodoh, siswa miskin-pintar, dan siswa miskin-bodoh. Keempat kategori tersebut berimplikasi pada pembedaan kesempatan siswa untuk mengakses fasilitas pendidikan. Siswa kaya-pintar memiliki kebebasan memilih sekolah, baik sekolah negeri (milik pemerintah) maupun swasta. Berbeda dengan siswa miskin-pintar yang harus berupaya mendapatkan beasiswa untuk terus bersekolah dengan modal prestasinya. Lain halnya lagi dengan siswa kaya-bodoh yang masih dapat bersekolah dengan mengandalkan modal ekonomi yang dimiliki orang tuanya. Siswa miskinbodoh bahkan memiliki paling sedikit kesempatan untuk dapat bersekolah. 
Pengelompokkan siswa berdasarkan latar belakang sosialnya tidak terlepas dari kepemilikan beberapa modal. Menurut Bourdieu (Martono, 2014), setidaknya ada empat modal yang mendukung keberhasilan siswa dalam pendidikan, yaitu: modal ekonomi, budaya, sosial, dan modal simbolik. Setiap siswa memiliki modal yang berbeda; modal tersebut akan berimplikasi pada habitus dan prestasi belajarnya. Modal yang dimiliki siswa dapat menentukan prestasi belajarnya di sekolah.

Modal ekonomi berkaitan dengan pemenuhan kebutuhan yang berkaitan dengan pendidikan, seperti buku pelajaran dan fasilitas belajar lainnya (laptop, smartphone, jaringan internet). Modal sosial berkaitan dengan jaringan sosial atau jaringan pertemanan yang dimiliki siswa. Semakin banyak jaringan sosial yang dimiliki, siswa akan semakin mudah mengakses ilmu pengetahuan, salah satunya melalui belajar kelompok. Modal budaya yang dimiliki siswa dapat berupa ide atau pengetahuan dan pengalaman sosial (pengalaman mengunjungi museum). Bagi siswa, fasilitas belajar dan jaringan pertemanan dapat menambah modal budaya. Ketika siswa telah memiliki modal budaya, maka siswa juga akan memperoleh modal simbolik berupa prestise atas prestasinya di sekolah. Keempat modal tersebut pada dasarnya saling berkaitan.

Siswa kelas atas secara teoretis merupakan siswa yang paling diuntungkan karena memiliki keempat modal tersebut, sehingga ia akan lebih mudah mencapai keberhasilan dalam studinya. Hal tersebut senada dengan penelitian (Kusuma, 2017) dan (Chotimah, Hety Mustika Ani, and Joko Widodo, 2017) yang menyatakan bahwa status sosial ekonomi orang tua berkaitan erat dengan prestasi siswa. Orang tua siswa kelas atas dapat memenuhi fasilitas belajar untuk menambah pengetahuan siswa, baik melalui les maupun bimbingan belajar online. Berbeda dengan siswa kelas bawah; mereka masih mengalami kesulitan memenuhi kebutuhan sehariharinya, apalagi untuk memenuhi kebutuhan pendidikan seperti buku pelajaran (LKS), alat tulis, laptop, maupun fasilitas lainnya (Chotimah et al., 2017).

Siswa kelas atas juga diuntungkan dengan kepemilikan modal sosial dan modal budaya. Modal sosial yang dimiliki siswa kelas atas dapat dimanfaatkan untuk bertanya mengenai pelajaran yang tidak dimengerti. Siswa kelas atas juga memiliki lebih banyak pengalaman melalui partisipasinya dalam beragam 
ekstrakurikuler, sehingga modal budayanya bertambah dan prestasi belajarnya meningkat (Swaramarinda and Henry Eryanto, 2013). Sebaliknya, siswa kelas bawah akan kehilangan banyak waktu belajar karena lebih sibuk melakukan pekerjaan domestik. Pengetahuan yang diperoleh siswa kelas atas melalui belajar bersama kemudian membentuk modal simbolik (Edgerton and Lance W. Roberts, 2014) yang berkaitan dengan pengakuan dan penerimaan publik secara luas (Umanailo, 2018).

Penelitian (Pramika et al., 2017) justru mengungkap hal yang berbeda, yaitu pendapatan orang tua tidak berhubungan dengan prestasi siswa karena kecerdasan siswa tidak hanya dipengaruhi faktor ekonomi. Penelitian (Nuraeni and Muhammad Syukur, 2018) mengenai habitus dan prestasi siswa seakan menguatkan argumen tersebut dengan mengatakan bahwa prestasi siswa dipengaruhi oleh kondisi badan (kesehatan), minat, motivasi, mood belajar, cita-cita dan rajin, fasilitas belajar, semangat belajar, bersaing dengan teman serta lingkungan belajar yang di dalamnya termasuk lingkungan keluarga, sekolah dan masyarakat-

Penelitian (Iksan, 2015) juga mengungkapkan bahwa kegagalan siswa baik dalam bidang akademik maupun nonakademik lebih disebabkan oleh perasaan malas belajar, menunda belajar serta kurangnya motivasi belajar. Siswa yang gagal berprestasi juga dapat disebabkan stress akademik yang dipengaruhi tekanan dari orang tua maupun teman sebayanya. Tekanan dari orang tua misalnya, orang tua siswa menuntut anaknya memiliki keunggulan akademik (Jayanti and Iwan Wahyu Hidayat, 2014). Hal tersebut berkaitan dengan anggapan bahwa anak yang memiliki kualifikasi akademik tinggi akan dihormati, disukai, dikenal, bahkan dipuji masyarakat. Siswa kelas atas harus memiliki kualifikasi akademik yang tinggi untuk mempertahankan status sosial orang tuanya.

Berdasarkan uraian tersebut, sebagian siswa kelas atas justru "gagal berprestasi”, sehingga studi mengenai kegagalan siswa kelas atas ini menjadi menarik untuk dikaji. Salah satu siswa dari keluarga kaya yang gagal berprestasi adalah Fahmi (nama samaran). Ia adalah siswa di salah satu SMA di Kota Cilacap, Jawa Tengah. Ayahnya bekerja di Badan Usaha Milik Negara (BUMN) di Kota Cilacap. Ia dan keluarganya tinggal di perumahan kompleks BUMN tempatnya 
bekerja. Fahmi sebenarnya memiliki modal ekonomi, budaya, sosial dan simbolik yang dapat digunakan untuk mencapai prestasi tinggi di sekolah.

Modal ekonomi yang dimiliki Fahmi antara lain jaringan internet, laptop, smartphone dan sebagainya, yang dapat dinilai dengan uang. Fahmi juga memiliki modal sosial berupa jaringan sosial yang luas dan didapatkan ketika ia berada di sekolah (dalam kegiatan ekstrakurikuler futsal) maupun kegiatan lain di luar sekolah (mengikuti les di salah satu bimbingan belajar). Modal budaya yang dimiliki oleh Fahmi antara lain pengalaman ketika menghabiskan libur akhir pekan bersama keluarga serta modal budaya berupa benda seperti buku bacaan penunjang belajar. Modal simbolik yang dimiliki Fahmi meliputi tempat tinggal elit (di kompleks perumahan $\mathrm{P} * \mathrm{rt} * \mathrm{~m} *$ na), kendaraan yang dipakai untuk sekolah serta kepemilikan fasilitas belajar lengkap.

Sementara, ibunya adalah ibu rumah tangga yang memiliki banyak waktu luang untuk mendampingi Fahmi. Namun kenyataannya, ia tidak mampu memanfaatkan modal yang dimilikinya, sehingga hasil belajarnya tidak cukup baik. Fahmi bahkan berada di peringkat dua terbawah di kelasnya. Menurut informasi dari guru BK (Bimbingan Konseling) di sekoahnya, ia dikenal sebagai siswa yang sering tidak masuk sekolah (membolos). Menurut catatan BK, orang tuanya berkali-kali dipanggil pihak sekolah karena perilaku Fahmi. Aktivitas nonakademik Fahmi juga kurang baik, Fahmi tidak pernah mengikuti kompetisi nonakademik apapun. Untuk itu, Fahmi menjadi sosok siswa yang menarik dikaji secara sosiologis.

Penentuan informan yaitu Fahmi berdasarkan rekomendasi dari guru BK yang memenuhi syarat berupa siswa kaya dan digolongkan sebagai siswa yang memiliki prestasi rendah di sekolah tersebut. Prestasi ini dilihat dari nilai rapor dan catatan perilaku siswa yang terekam di BK. Di kalangan guru wali kelas dan guru BK, Fahmi dikenal sebagai siswa yang sering membolos, hingga kedua orangtuanya beberapa kali diundang ke sekolah. Secara sosial, Fahmi termasuk siswa yang berasal dari keluarga kaya karena status pekerjaan ayahnya yang bekerja di salah satu BUMN di Kota Cilacap. Namun status sosial tersebut ternyata tidak berimplikasi pada capaian pembelajaran Fahmi. Untuk itu, penelitian ini akan mengungkap cerita di balik kegagalan Fahmi mencapai prestasi di sekolahnya. 


\section{METODE PENELITIAN}

Penelitian ini dilakukan menggunakan kolaborasi dua metode yaitu: life history dan studi kasus. Life history menekankan pada pengalaman hidup seseorang yang berasal dari kelompok sosial tertentu sesuai dengan tahap-tahap dan fase hidup yang dilalui individu. Biasanya pengalaman itu berkaitan dengan pendidikan. Studi kasus berusaha untuk mengeksplorasi suatu kasus secara mendalam dan komprehensif. Cakupan wilayah dalam studi kasus pun relatif sempit, karena mengkaji perilaku pada tingkat individu, lembaga maupun organisasi, bukan masyarakat luas. Studi kasus dilakukan dengan menggali catatan harian kegiatan informan hingga riwayat hidup atau rekam jejak informan sehingga memperoleh gambaran yang utuh. Kedua metode tersebut dikombinasikan untuk mendapatkan deskripsi yang benar-benar mendalam dan menyeluruh berkaitan dengan latar kehidupan Fahmi sejak SD-SMA serta menggambarkan kasus yang dialami Fahmi .

Penentuan informan dilakukan menggunakan teknik purposive sampling dengan kriteria penentuan informan adalah siswa dari kelas atas yang gagal berprestasi di sekolah. Penelitian ini dilakukan di salah satu SMA di Kota Cilacap, Jawa Tengah. Penelitian ini juga dilakukan di tempat tinggal siswa untuk mengetahui kondisi ekonomi orang tua siswa. Pengumpulan data dilakukan dengan menggunakan metode wawancara dengan siswa, teman dekat siswa, orang tua siswa, dan guru BK. Pengumpulan data juga dilakukan dengan observasi kondisi rumah siswa beserta dengan fasilitas belajarnya, serta dokumentasi yang dilakukan dengan mengumpulkan data nilai mata pelajaran. Analisis data yang dilakukan dalam penelitian ini menggunakan analisis model interaktif.

\section{PEMBAHASAN}

\section{Latar Kehidupan Fahmi}

Fahmi lahir di Cilacap pada tahun 2002. Ia merupakan anak kedua dari lima bersaudara. Kakaknya sedang menempuh pendidikan tinggi di salah satu Politeknik Negeri di Kota Semarang, sementara adik pertamanya masih duduk di kelas XI di sekolah yang sama dengan Fahmi. Dua adik lainnya masih balita dan ada salah satu yang sedang bersekolah di playgroup. Ayahnya bekerja di salah satu Badan Usaha 
Milik Negara (BUMN) di Kota Cilacap, sedangkan ibunya adalah seorang ibu rumah tangga. Hubungan antara Fahmi dengan orang tuanya tidak terlalu baik, karena mereka sangat jarang berkomunikasi di rumah.

Meskipun hubungan dengan orang tuanya tidak terlalu baik, Fahmi mengaku bahwa saat SD masih sering menghabiskan waktu bersama dengan keluarganya yaitu pada saat libur sekolah maupun akhir pekan. Di rumahnya ada seorang pembantu rumah tangga yang bertugas untuk menyelesaikan pekerjaan rumah. Oleh karenanya, sepulang sekolah Fahmi tidak melakukan pekerjaan rumah tangga apapun. Sejak playgroup hingga SMP Fahmi menempuh pendidikan di sekolah swasta yang tidak jauh dari rumahnya. Selama itu pula Fahmi diantar jemput orang tuanya. Ia menuturkan:

"Playgroup, TK sampai SD-nya di $B^{* *} S$, kalo berangkat sekolah dianter orang tua" (Fahmi, 04 Maret 2020).

Menurut keterangan Fahmi, sebelum memasuki usia sekolah orang tuanya tidak pernah mengajari baca tulis. Fahmi belajar baca tulis ketika telah memasuki playgroup, Taman Kanak-Kanak (TK) dan Sekolah Dasar (SD), sehingga ia diajari baca tulis oleh gurunya. Hal tersebut membuatnya tidak suka belajar sejak kecil karena tidak terbiasa untuk belajar. Berikut penuturannya:

"Dari kecil nggak suka belajar, gimana ya? Nggak suka aja gitu” (Fahmi, 04 Maret 2020).

Fahmi kemudian menceritakan pengalaman yang tidak dapat ia lupakan ketika masih berada di TK. Ia dan teman-temannya pernah membolos dan pergi meninggalkan sekolahan. Ia mengatakan:

"Dulu waktu TK pernah bolos sama temen, kabur dari TK. Pas di jalan malah ketemu ibu saya, terus dianterin ke sekolah lagi sama ibu saya. Di sekolah malah saya dimarahi oleh guru” (Fahmi, 04 Maret 2020).

Alhasil, Fahmi mendapat teguran dari guru dan orang tuanya. Perilaku membolosnya ternyata berlanjut hingga ia duduk di bangku SMA. Perilakunya tersebut seolah sudah menjadi sebuah kebiasaan baginya yang sulit dihilangkan. Memasuki kelas satu SD, Fahmi merasa bahwa dirinya masih mampu bersaing dengan temannya dalam hal akademik karena materi pelajaran tidak terlalu sulit dan -katanya- tidak membutuhkan belajar, hanya seputar baca tulis. Hal tersebut 
membuat Fahmi selalu mendapatkan apa yang diinginkan sebagai hadiah atas prestasinya. Namun setelah berada di kelas empat, ia mulai malas belajar karena bukan lagi seputar baca tulis, sehingga prestasi belajarnya menurun. Ia menyadari bahwa sekolah memang penting, tetapi ia juga menuturkan:

“...sekolah kayaknya penting si, cuma males aja belajarnya karena semua dipelajari si. Maksudnya kayak semua pelajaran dipelajari padahal menurutku nggak penting-penting amat” (Fahmi, 04 Maret 2020).

Rasa malas belajar yang membuat prestasinya menurun ditanggapi orang tua Fahmi dengan kemarahan. Meskipun demikian sebagai anak dari keluarga berada, Fahmi selalu mendapat fasilitas belajar yang terbaik dari orang tuanya. Hal tersebut dibuktikan dari ketersediaan berbagai macam buku penunjang belajar serta keikutsertaannya dalam les privat. Fahmi mengaku bahwa orang tuanya menyuruh Fahmi mengikuti les di salah satu lembaga bimbingan belajar setelah mengetahui prestasinya menurun. Les privat tersebut berlangsung selama dua tahun saat kelas empat dan kelas lima SD. Akan tetapi, ia justru merasa tidak mendapatkan manfaat dari keikutsertaannya di tempat les sehingga prestasi belajarnya tidak menunjukkan peningkatan berarti.

Ketika Fahmi SD, ia pernah mendapat tawaran untuk mengikuti lomba lari (atletik), namun sekolahnya batal mengirimkan wakilnya. Penunjukkan Fahmi sebagai wakil sekolah untuk mengikuti lomba lari tersebut dilakukan guru olah raganya yang melihat potensi Fahmi dalam bidang olahraga, khususnya cabang olahraga atletik. Sebelum sekolah Fahmi membatalkan keikutsertaannya dalam perlombaan, Fahmi mengaku telah berlatih keras. Namun ia merasa tidak terlalu kecewa dengan pembatalannya mengikuti lomba tersebut. Selain dilihat memiliki potensi di bidang olahraga atletik, Fahmi juga gemar bermain sepak bola. Namun, kegemarannya itu membuat dirinya mendapat marah dari guru SD-nya. Ia menceritakan:

"Waktu SD pernah dimarahin guru gara-gara main bola di perpustakaan sama temen-temen” (Fahmi, 04 Maret 2020).

Prestasi belajar Fahmi ketika di SMP semakin menurun karena ia semakin malas belajar. Ia beralasan: 
“...kalo prestasi belajar di SMP kayaknya menurun lho, karena dari kelas 8 (delapan) sampe kelas 9 (sembilan) tambah males belajar. Apalagi dapet temen yang kayak gitu juga, maksudnya sama-sama males belajar. Terus mereka juga lebih sering main daripada belajar” (Fahmi, 04 Maret 2020).

Meskipun orang tua Fahmi masih sering marah karena prestasi belajarnya kian menurun, Fahmi tetap malas belajar dan lebih suka bermain dengan temantemannya. Ia merasa lebih nyaman ketika bersama dengan teman-temannya dibandingkan ketika bersama dengan orang tuanya. Fahmi menilai bahwa cara mengajar guru SMP-nya cukup menyenangkan, sama seperti saat ia masih SD. Namun, penilaian tersebut tidak membuatnya termotivasi belajar. Pasalnya, guru di sekolah swasta akan memberikan materi dan contoh soal menjelang ulangan harian dan contoh soal yang disampaikan juga mirip dengan yang diujikan, sehingga membuat Fahmi menjadi malas untuk belajar di rumah (belajar sendiri). Kebiasaan membolos yang dilakukan Fahmi masih berlanjut hingga ia berada di SMP. Kebiasaan tersebut bahkan membuat dirinya kehilangan kesempatan untuk mengikuti seleksi tim futsal SMP-nya. Ia mengatakan bahwa:

“ Waktu itu lagi sakit apa lagi bolos gitu, lupa. Tapi ada seleksi tim futsal sekolah gitu lho, jadi nggak ikut. Eh kayaknya bolos si... Aku juga jarang ikut ekskulnya jadi nggak tau kalo ada seleksi” (Fahmi, 04 Maret 2020).

Untuk menghadapi Ujian Nasional (UN) SMP, Fahmi mengikuti ajakan temannya untuk memperoleh tambahan belajar melalui les. Fahmi merasa bahwa keikutsertaannya dalam les tersebut cukup membantu nilai mata pelajaran bahasa Inggris, bahasa Indonesia, dan IPA. Di sisi lain, ia juga mengatakan bahwa les tersebut tidak cukup membantu memperbaiki nilai mata pelajaran Matematika-nya.

Tidak seperti saat masih SD, Fahmi sudah jarang menghabiskan waktu liburan dan akhir pekannya bersama orang tua saat SMP. Ia juga mengatakan bahwa lebih sering menghabiskan waktunya bersama dengan teman-teman. Fahmi dan teman-temannya menghabiskan lebih banyak waktu untuk nongkrong daripada belajar bersama. Meskipun demikian, Fahmi masih menuruti saran dari orang tuanya mengenai pilihan sekolah lanjutannya. Ia mengatakan:

“...kan orang tua penginnya aku di sini, kakak juga dulu alumni sini, ya udah di sini aja. Asalnya si pengin di SMA ***, cuma nggak ada temennya juga si..." (Fahmi, 04 Maret 2020). 
Ia lebih lanjut menjelaskan:

“...aslinya di SMA *** banyak temen, tapi orang tua kayak nyaranin di SMA ini aja lah. Ya udah kayak gitu” (Fahmi, 04 Maret 2020).

Keputusan Fahmi untuk bersekolah di salah satu SMA negeri di Cilacap yang bukan merupakan keinginannya membuat Fahmi lebih malas untuk belajar. Hal tersebut juga diperparah dengan jurusannya di SMA. Ia merasa bahwa pilihannya masuk IPS adalah hal yang salah karena jurusan impiannya adalah IPA. Ia mengatakan:

"Tambah males si, jujur aja. Awalnya kan penginnya IPA, dari SMP juga udah serius belajar IPA tapi nilainya masih jelek, jadi IPS aja lah. Juga belum tau cita-cita si, jadi masih asal milih gitu” (Fahmi, 04 Maret 2020).

Ia pun merasakan perbedaan ketika bersekolah di sekolah swasta dan di sekolah negeri. Perbedaan yang dirasakannya:

"Guru di sekolah negeri sama di sekolah swasta cara ngajarnya agak beda, tapi swasta sama negeri kayaknya emang beda lho...kayak gimana ya? Kalo guru di sekolah swasta kayak lebih perhatian gitu..." (Fahmi, 04 Maret 2020).

Fahmi juga mengatakan bahwa orang tuanya masih sering marah apabila hasil belajarnya rendah, sehingga Ia memutuskan untuk mengikuti les privat di salah satu lembaga bimbingan belajar di Cilacap. Meskipun hal tersebut adalah pilihannya sendiri, tetapi Fahmi kurang memiliki niat dan motivasi dalam mengikuti les, karena ia merasa bahwa kegiatan tersebut tidak membantu menaikkan prestasi belajarnya.

"Ya awalnya niat, cuma lama-lama jadi gitu lah. Nggak niat dari saya sendiri lho... Lesnya kan buat nambah nilai di sekolah, tapi sekarang saya lebih mikir buat besok lho... buat masuk Perguruan Tinggi (PT) lah daripada nilai sekolah" (Fahmi, 04 Maret 2020).

Ketika di SMA, Fahmi masih sering membolos, sehingga gurunya sering memanggil orang tua Fahmi ke sekolah. Padahal, orang tua Fahmi mengetahui bahwa anaknya telah berangkat ke sekolah. Kebiasaan buruk yang dilakukan Fahmi sering membuat orang tuanya marah. Keterangan ini juga dibenarkan guru BK-nya.

Lingkungan pertemanan Fahmi di SMA juga tidak jauh berbeda dari lingkungan pertemanan sebelumnya. Fahmi memang mengikuti ekstrakurikuler futsal, tapi ia mengaku jarang berangkat karena malas dan teman-temannya juga lebih sering mengajak nongkrong. Kegiatan yang dilakukan saat nongkrong adalah 
bermain handphone atau sekedar mengobrol. Meskipun kadang kala ada teman Fahmi yang mengajak belajar kelompok dan mengerjakan PR, Fahmi lebih sering meminta jawaban kepada teman-temannya. Hal tersebut justru membuat prestasinya tertinggal jauh dari teman-temannya.

Kehidupan Fahmi jauh dari keluarganya dan lebih dekat dengan temantemannya. Fahmi merasa bahwa Ia tidak mendapat perhatian lebih dari orang tuanya, khususnya dalam hal pendidikan. Hal tersebut membuat Fahmi enggan bercerita kepada orang tua mengenai permasalahan yang dihadapinya di sekolah karena ia pun sadar bahwa orang tuanya tidak pernah ingin tahu mengenai pendidikannya. Menurutnya, ibunya tidak pernah bertanya mengenai tugas yang diberikan gurunya. Fahmi menyampaikan:

“...di rumah nggak ada yang ngajarin belajar. Papah sibuk kerja, ibu juga nggak pernah tanya-tanya kek misal: ada tugas apa? Apa gimana gitu...jadi males cerita gitu” (Fahmi, 04 Maret 2020).

Orang tua Fahmi memberikan perhatian dengan memberikan fasilitas belajar yang lengkap seperti: internet di rumah, buku pelajaran, hingga biaya les. Tetapi Fahmi justru tidak memanfaatkan fasilitas tersebut dengan baik. Ia mengaku bahwa fasilitas Wifi yang diberikan orang tuanya digunakan untuk menonton video di Youtube.

\section{Alasan di Balik Kegagalan Fahmi di Sekolah}

Cerita singkat mengenai kehidupan Fahmi menunjukkan bahwa tidak selamanya siswa kaya selalu berhasil mengukir prestasi di sekolah sebagaimana "mitos" yang disampaikan para penganut teori fungsional dan konflik. Dalam praktiknya, tidak semua siswa yang berasal dari kelas atas dapat berprestasi karena pencapaian prestasi tidak semata ditentukan kelas sosial siswa. Habitus yang dilekatkan pada kelas sosial tertentu juga tidak selamanya berlaku mutlak. Seperti siswa kelas atas yang memiliki habitus rajin, disiplin, tekun dan kompetitif sehingga mereka dapat berprestasi. Padahal, siswa kelas atas juga dapat gagal berprestasi karena tidak memiliki habitus berprestasi yang lain seperti belajar dengan konsentrasi, mendengarkan guru, aktif bertanya dan menjawab, membaca dan membuat catatan, membuat jadwal belajar dan pelaksanaannya, mengatur waktu 
belajar, mengulang pelajaran, mengerjakan PR dan menghafal pelajaran. Siswa kaya yang gagal berprestasi dianggap memiliki habitus seperti yang melekat pada siswa miskin, seperti malas belajar, tidak disiplin dan pembangkang (Umanailo, 2018) serta memiliki habitus kelas terdominasi seperti pendiam, penakut, terlalu patuh, pasrah pada nasib, tidak kreatif, hanya beribadah tetapi tidak berusaha, dan sebagainya. Fahmi tidak memiliki habitus berprestasi karena tidak dapat memanfaatkan modal ekonomi, budaya, sosial dan modal simbolik yang dimilikinya dengan baik.

Seperti yang telah disebutkan sebelumnya bahwa modal yang dimiliki individu akan membentuk berbagai habitus, termasuk pola pikir dan pola perilaku yang terbentuk secara terus menerus dalam waktu lama, sehingga menjadi praktik kehidupan sehari-hari yang tidak disadari (Siregar, 2016). Habitus dipahami sebagai dasar kepribadian individu dan habitus tidak terbentuk secara tiba-tiba, melainkan melalui proses panjang yang berupa pengalaman sejarah individu ketika berinteraksi dengan lingkungan sosialnya. Pengalaman yang membentuk habitus belajar Fahmi di antaranya mengikuti les privat, membolos ketika masih TK bersama dengan teman-temannya dan sebagainya.

Meskipun setiap kelas sosial akan memiliki habitus yang ditentukan modal yang dimilikinya, sebagian habitus juga berkembang dari pengalaman dan internalisasi nilai di lingkungan baru melalui sosialisasi. Habitus dibangun melalui proses pendidikan yang oleh Bourdieu dibagi menjadi tiga hal yaitu pendidikan keluarga, pendidikan sosial, dan pendidikan sekolah (Wempi, 2012). Pendidikan keluarga mengajarkan bagaimana individu seharusnya berperan dalam masyarakat dan keluarga merupakan agen sosialisasi habitus yang pertama sebelum individu mengenal pendidikan sosial dan pendidikan sekolah. Pembentukan habitus tersebut dilakukan oleh banyak agen, salah satunya adalah sekolah. Sekolah diyakini sebagai agen yang paling berperan dalam proses sosialisasi habitus (Celik, 2017). Di sekolah, siswa akan belajar nilai dan norma yang tidak mereka dapatkan di lingkungan keluarga. Nilai dan norma yang dimaksud antara lain datang ke sekolah tepat waktu, memiliki kemandirian dan tanggung jawab pribadi dalam mengerjakan tugas sekolah tanpa bantuan orang tua dan sebagainya. 
Sosialisasi habitus di sekolah dilakukan guru melalui peraturan sekolah mengenai kewajiban memakai seragam, metode atau cara mengajar guru, gaya berjalan, gaya berbicara, gaya berpakaian dan sebagainya. Melalui interaksi yang terjadi diantara siswa, habitus, budaya dan selera dapat terinternalisasi (Mua, 2015). Sosialisasi habitus yang dilakukan guru pada dasarnya merupakan penggambaran habitus kelas atas di sekolah. Fahmi yang merupakan siswa dari kalangan atas sejak playgroup terbiasa bersekolah di sekolah swasta, tetapi ia bersekolah di sekolah negeri saat SMA. Saat berada di SMA, ia merasa bahwa cara guru mengajar di sekolah negeri berbeda dengan cara guru mengajar di sekolah swasta. Ia beranggapan bahwa peran guru sangat besar dalam membentuk habitus siswa, terutama melalui metode pembelajaran seperti mengerjakan dan menghapal soal sebelum ulangan harian. Kebiasaan memberikan soal ulangan sebelumnya tidak ia temukan ketika bersekolah di sekolah negeri, sehingga ia harus memiliki etos yang berbeda. Sayangnya, cara guru SMA mengajar justru membuat Fahmi menjadi semakin malas belajar sendiri dan lebih mengandalkan metode hapalan soal, karena soal yang diberikan guru sebelumnya kemungkinan besar akan keluar di ulangan.

Selain itu, menghapal soal yang diberikan oleh guru sebelum ulangan dirasa cukup untuk mendapatkan nilai yang tinggi, tanpa harus membaca materi secara keseluruhan. Hal tersebut juga berdampak pada kurang berkembangnya daya berpikir siswa untuk mengeksplorasi dan memberikan argumentasi pada jawaban ujian mereka. Metode menghapal yang diterapkan oleh gurunya juga menjadikan Fahmi tidak memiliki kemandirian belajar. Kemandirian belajar berkaitan dengan kegiatan belajar yang dilakukan sendiri atau tanpa melibatkan pihak lain. Ciri seorang siswa yang memiliki kemandirian belajar antara lain mengerjakan tugas sendiri, memiliki inisiatif belajar, tidak menyontek saat ujian dan sebagainya. Berdasarkan ciri tersebut, Fahmi tidak memiliki kemandirian belajar.

Rasa malas belajar dapat berupa tidak mengerjakan pekerjaan rumah (PR), malas mempelajari mata pelajaran di sekolah, menunda-nunda pekerjaan bahkan tidak mengikuti pembelajaran di kelas (Megayanti, 2016). Siswa yang memiliki perasaan malas belajar karena tidak memiliki motivasi belajar juga dicirikan dengan beberapa hal seperti kurang bekerja keras, mudah putus asa, tidak menyenangi tugas 
serta tidak bertanggung jawab terhadap tugasnya. Secara sosiologis, malas belajar juga dapat disebabkan tuntutan sekolah kepada siswanya untuk menguasai semua mata pelajaran. Padahal menurut pandangan Fahmi, tidak semua mata pelajaran penting dan dapat diterapkan dalam kehidupan sehari-hari. Oleh karenanya, ia menjadi malas untuk mempelajarinya. Keadaan tersebut juga menyebabkan Fahmi sering membolos dan tidak mengikuti pembelajaran di kelas.

Selain dilakukan guru, sosialisasi habitus juga "dibentuk" teman sekolahnya. Selama menempuh pendidikan dari playgroup hingga SMA, Fahmi berteman dengan teman yang sama-sama tidak terbiasa belajar. Mereka lebih sering nongkrong daripada belajar kelompok. Hal tersebut diakui Fahmi semenjak ia berada di SMP dan SMA. Terlebih teman sebaya Fahmi juga enggan untuk menyelesaikan PR bersama. Bahkan Fahmi juga menyatakan bahwa ia lebih sering meminta jawaban PR temannya daripada mengerjakan sendiri. Hal tersebut membuat Fahmi tidak menggunakan kemampuan berpikirnya dan cenderung mengabaikan tanggung jawabnya. Siswa yang terbiasa menyontek juga akan memiliki rasa ketergantungan terhadap orang lain sehingga apabila tidak ada orang lain yang membantu, mereka akan lebih mudah menyerah.

Fahmi menganggap bahwa teman sekolahnya hanya sebagai teman bermain (nongkrong), bukan teman belajar. Padahal, apabila Fahmi memanfaatkan jaringan pertemanan tersebut, bukan tidak mungkin prestasi belajarnya akan meningkat. Apalagi Fahmi memiliki banyak teman, bukan hanya teman sekelas tetapi juga teman yang ditemuinya saat mengikuti kegiatan ekstrakurikuler (futsal). Jaringan pertemanan sebagai modal sosial dapat dimanfaatkan untuk menanyakan mata pelajaran yang sulit dipelajari sehingga dapat digunakan untuk mengatasi masalah kesulitan belajar. Apabila hal tersebut benar-benar dilakukan oleh Fahmi, kemungkinan juga modal budaya Fahmi akan bertambah sehingga prestasi belajarnya meningkat. Sayangnya, jaringan pertemanan yang dimiliki Fahmi diisi orang-orang yang tidak membuatnya termotivasi belajar. Aktivitas yang dilakukan Fahmi dan teman sekolahnya saat nongkrong bersama pun hanya sebatas bermain game online bersama atau sekedar ngobrol. Terkadang, mereka juga melakukan konvoi setelah nongkrong dan hendak pulang ke rumah masing-masing. 
Hubungan yang kurang baik diantara Fahmi dan orang tuanya juga membuat Fahmi lebih senang bercerita kepada temannya, termasuk masalah di sekolah seperti kesulitan belajar. Teman sebaya kemudian menjadi sumber dukungan sosial karena dapat memberikan rasa senang dan motivasi ketika siswa mengalami sebuah permasalahan. Dalam hal ini, teman sebaya dianggap sebagai pengganti keluarga dan tempat untuk berkeluh kesah. Anak-anak lebih bergantung kepada temannya daripada orang tuanya untuk memuaskan kebutuhan akan rasa kebersamaan, kepastian dan kedekatan yang tidak didapatkan di keluarga (Santrock, 2011). Kebersamaan dan interaksi antara siswa dengan temannya itulah yang menyebabkan anak-anak akan cenderung lebih dekat dengan temannya daripada dengan orang tuanya. Kedekatan dengan teman biasanya dibuktikan dengan pemberian dukungan sosial, moral dan emosional kepada teman sebayanya yang membuat siswa lebih nyaman untuk bercerita mengenai segala permasalahannya kepada teman, daripada bercerita kepada orang tua atau guru mereka (Kurniawan and Ajat Sudrajat 2018).

Habitus adalah produk sejarah yang terbentuk sejak manusia lahir dan berinteraksi dengan masyarakat dalam ruang dan waktu. Habitus merupakan hasil pembelajaran lewat pengasuhan, aktifitas keseharian dan pendidikan keluarga (Miyarso 2017). Dengan demikian, habitus dimaknai sebagai hasil dari kultur keluarga. Setiap keluarga memiliki pasti kultur yang berbeda sehingga menghasilkan habitus yang berbeda pula. Habitus tersebut tentu saja terbentuk berdasarkan modal yang dimiliki tiap keluarga. Modal ekonomi misalnya, keluarga kelas atas menyediakan fasilitas seperti handphone untuk menunjang belajar anak sehingga anak diharapkan memiliki habitus senang belajar. Kenyatannya, fitur yang ada di handphone bukan hanya dimanfaatkan untuk kegiatan belajar tetapi juga bermain game online. Seperti Fahmi yang memanfaatkan handphone dan jaringan internetnya untuk bermain game online, sehingga Fahmi lebih memiliki habitus senang bermain. Kebiasaan bermain game online dapat terjadi ketika pengawasan orang tua lemah terhadap penggunaan handphone dan jaringan internet yang digunakan oleh anak-anaknya (Amaruddin, Hamdan Tri Atmaja, and Muhammad Khafid, 2020). Hal tersebut juga berarti orang tua tidak sekedar menyediakan 
fasilitas tetapi juga mengatur penggunaan fasilitas yang diberikan agar digunakan dengan semestinya.

Siswa dari keluarga kaya juga dapat saja memiliki habitus malas karena semua kebutuhan dalam bidang pendidikannya dapat dengan mudah terpenuhi. Mereka tidak perlu rajin dan bekerja keras untuk memenuhi kebutuhannya karena telah disediakan oleh orang tua. Selain itu, siswa kelas atas dapat menggunakan modal ekonomi yang dimilikinya untuk membeli buku. Mereka juga memiliki waktu luang karena terbebas dari tuntutan kerja-kerja ekonomis dan non-ekonomis. Hakikatnya, waktu luang tersebut seharusnya dapat digunakan untuk membaca buku atau sekedar mengulang pelajaran di sekolah. Dalam kasus Fahmi, ia dibebaskan oleh tugas-tugas rumah tangga karena memiliki pembantu rumah tangga dan waktu luang yang dimilikinya justru tidak digunakan untuk membaca melainkan untuk nongkrong bersama dengan teman sebayanya. Orang tua yang membebaskan anaknya dari pekerjaan rumah tangga justru akan membuat anak tidak memiliki tanggung jawab (Siregar, 2013). Seperti yang terjadi pada Fahmi dimana ia menjadi tidak bertanggung jawab terhadap tugas sekolahnya dan ia memiliki kebiasaan menyalin pekerjaan rumah milik temannya.

Keluarga merupakan elemen penting dalam pembentukan habitus karena beragam praktik dan persepsi individu pertama kali didapat melalui lingkungan keluarga (Miyarso, 2017). Selain itu, peran keluarga dalam pembentukan habitus sangat penting, mengingat habitus merupakan sesuatu yang dapat dengan mudah dialihkan dan diwariskan (transposables) dari satu generasi ke generasi lainnya. Habitus yang diproduksi melalui pengalaman yang bersifat ekonomis dan sosial juga terjadi dalam lingkup keluarga. Pengalaman yang dimaksud seperti pengalaman bertamasya mengunjungi museum bersama dengan keluarga saat hari libur atau akhir pekan dan sebagainya. Melalui pengalaman itulah individu akan memperoleh modal budaya yang berupa pengetahuan, berbagai informasi serta nilai-nilai.

Siswa yang datang ke sekolah juga telah membawa habitus masing-masing yang diproduksi dan disosialisasikan di lingkungan keluarga dan masyarakat tempat ia tinggal (Martono et al. 2019). Meskipun demikian, habitus dapat berubah seiring dengan kondisi yang dihadapi oleh individu di sekolah melalui proses adaptasi. 
Fahmi memperoleh habitus membaca dan menulis ketika telah memasuki usia sekolah, padahal Fahmi tidak pernah memiliki kebiasaan tersebut sebelum memasuki usia sekolah. Selain itu ketika di sekolah, Fahmi dituntut untuk memiliki habitus rajin belajar agar dapat bersaing dengan temannya, begitu pula ketika ia mengikuti tambahan belajar di tempat les. Orang tua Fahmi menginginkan Fahmi untuk bersekolah di SMA negeri yang berlabel sekolah favorit, sama seperti tempat kakaknya menimba ilmu. Sekolah favorit dianggap sebagai sekolah yang mahal dan tempat orang kaya bersekolah (Martono et al. 2019). Oleh karenanya banyak orang tua yang menginginkan anaknya untuk bersekolah di sekolah favorit, tak terkecuali orang tua Fahmi. Hal tersebut juga berkaitan dengan kondisi dimana kelas atas berusaha untuk mempertahankan status sosialnya melalui pendidikan. Orang tua kelas atas cenderung memasukkan anak-anak mereka ke dalam sistem pendidikan dengan kurikulum yang sesuai dengan tradisi mereka, sehingga anak-anak mereka dapat tumbuh dan berkembang sesuai dengan keinginan orang tua.

Dukungan orang tua pada dasarnya memberikan kontribusi besar terhadap perkembangan belajar anak. Dalam kasus Fahmi, dukungan yang diberikan orang tuanya lebih berupa dukungan fisik (pemenuhan fasilitas belajar), bukan dukungan non-fisik seperti perhatian dan motivasi. Padahal perhatian orang tua terhadap kegiatan belajar anak dapat menambah motivasi belajar, sehingga prestasi belajarnya dapat meningkat. Di lain sisi, ketidakpedulian orang tua terhadap kegiatan belajar anak akan membuat orang tua tidak mengetahui perkembangan prestasi belajar anaknya (Rahayu, 2011). Fahmi mengatakan bahwa dirinya sering dimarahi oleh orang tuanya. Hal tersebut justru hanya memperparah keadaan dan menambah rasa malas belajar serta tidak menumbuhkan motivasi belajar. Ketika terjadi penurunan prestasi belajar atau bahkan kegagalan berprestasi, orang tua seharusnya mencari penyebab dan solusi serta memberikan motivasi supaya anak-anaknya memiliki semangat belajar kembali.

Secara umum, habitus mencakup tiga peran yaitu (habitus x modal) + arena = praktik. Habitus yang diterapkan di sekolah dipandang sebagai habitus kelas atas dan siswa yang berprestasi ialah siswa yang memiliki habitus kelas atas. Pada kenyataannya, hal tersebut tidak berlaku secara keseluruhan. Kelas atas juga 
memiliki habitus kelas terdominasi (kelas bawah) seperti malas belajar, senang bermain dan senang membolos yang menyebabkan mereka gagal berprestasi di sekolah.

\section{KESIMPULAN}

Keluarga dari kelas atas dapat mempergunakan modal ekonomi, budaya, sosial dan modal simbolik yang dimilikinya untuk menunjang prestasi belajar di sekolah. Akan tetapi melalui kasus Fahmi seolah ditunjukkan bahwa, siswa dari kelas atas tidak dapat memanfaatkan modal yang dimilikinya dengan baik, sehingga mereka mengalami kegagalan dalam belajar. Selain itu, kegagalan berprestasi yang dialami Fahmi disebabkan karena ia memiliki habitus membolos, habitus malas belajar, habitus senang bermain dan gemar menyontek. Habitus tersebut pada dasarnya terbentuk melalui sosialisasi habitus di sekolah yang dilakukan oleh guru dan teman sekolahnya serta sosialisasi habitus di lingkungan keluarga dimana Fahmi tinggal. Jadi, kegagalan yang dialami Fahmi disebabkan oleh kegagalan sosialisasi habitus berprestasi. Sekolah menjadi salah satu agen pembentuk habitus malas belajar siswa oleh karena itu, sekolah dapat menerapkan gerakan literasi untuk menumbuhkan semangat membaca dan menulis siswa. Untuk menunjang kegiatan tersebut, sekolah juga perlu menyediakan sarana pendukung berupa berbagai macam buku maupun jaringan internet.

\section{DAFTAR PUSTAKA}

Amaruddin, Hidar, Hamdan Tri Atmaja, \& Muhammad Khafid. 2020. "Peran Keluarga Dan Media Sosial Dalam Pembentukan Karakter Santun Siswa Di Sekolah Dasar." Jurnal Pendidikan Karakter 10(1):33-48. doi: 10.21831/jpk.v10i1.30588.

Celik, Cetin. 2017. "Institutional Habitus and Educational Achievement: A Comparative Case Study in Germany and Turkey.” Istanbul: Istanbul Police Center.

Chotimah, Lilis Nur, Hety Mustika Ani, \& Joko Widodo. 2017. "Pengaruh Status Sosial Ekonomi Orang Tua Terhadap Prestasi Belajar Siswa." Jurnal Pendidikan Ekonomi: Jurnal Ilmiah Ilmu Pendidikan, Ilmu Ekonomi Dan Ilmu Sosial 11(1):75-80. doi: 10.19184/jpe.v11i2.6457.

Edgerton, Jason D., \& Lance W. Roberts. 2014. "Cultural Capital or Habitus? Bourdieu and Beyond in the Explanation of Enduring Educational Inequality." 
Theory and Research in Education 12(2):193-220. doi: $10.1177 / 1477878514530231$.

Idi, Abdullah, \& Safarina. 2016. Sosiologi Pendidikan (Individu, Masyarakat Dan Pendidikan). Depok: PT RajaGrafindo Persada.

Iksan, Mohamad. 2015. "Atribusi Kegagalan Berprestasi Siswa SMP Dan SMA.” Jurnal Psikologi Tabularasa 10(2):172-85 (http://jurnal.unmer.ac.id/index.php/jpt/article/download/1398/900).

Jayanti, Rahma, \& Iwan Wahyu Hidayat. 2014. "Hubungan Antara Tuntutan Orangtua Terhadap Prestasi Dengan Perfeksionisme Pada Anak Berbakat Di SMA Negeri 1 Gresik.” Psikologi Klinis Dan Kesehatan Mental 3(3):153-58 (https://www.google.com/url?q=http://journal.unair.ac.id/download-fullpapersjpkk285e57b80cfull.pdf\&sa=U\&ved=2ahUKEwiQ4tqkxPfuAhXDqksFHeYiC dlQFjAJegQlBxAB\&usg=AOvVaw20eXDPtCuWC6gkKtyAqaAG).

Kurniawan, Yusuf, \& Ajat Sudrajat. 2018. "Peran Teman Sebaya Dalam Pembentukan Karakter Siswa Madrasah Tsanawiyah." SOCIA: Jurnal IlmuIlmu Sosial 15(2):149-63. doi: 10.21831/socia.v15i2.22674.

Kusuma, Unggul Pradana. 2017. "Pengaruh Status Orang Tua Dan Lingkungan Terhadap Prestasi Belajar Siswa Kelas XI SMK Negeri 1 Depok Sleman." Hisbah: Jurnal Bimbingan Konseling Dan Dakwah Islam 14(2):43-53. doi: 10.14421/hisbah.2017.142-04.

Martono, Nanang. 2014. "Dominasi Kekuasaan Dalam Pendidikan: Tesis Bourdieu Dan Foucault Tentang Pendidikan Tesis Bourdieu Dan Foucault Tentang Pendidikan." Jurnal Interaksi 8(1):28-39 (https://www.researchgate.net/publication/325119775_DOMINASI_KEKUAS AAN_DALAM_PENDIDIKAN_Tesis_Bourdieu_dan_Foucault_tentangPendidikan).

Martono, Nanang, Elis Puspitasari, Mintarti, \& Sulyana Dadan. 2019. Kontestasi Habitus Di Sekolah Publik. Depok: PT RajaGrafindo Persada.

Megayanti. 2016. "Identifikasi Faktor-Faktor Penyebab Siswa Malas Belajar Pada Kelas V." Jurnal Pendidikan Dan Guru Sekolah Dasar 30(5):2848-53 (journal.student.uny.ac.id/ojs/index.php/pgsd/article/view/4927).

Miyarso, Estu. 2017. "Kultur Keluarga Dan Kemampuan Berbahasa Anak.” Jurnal Dinamika Pendidikan 22(2):97-111

(https://journal.uny.ac.id/index.php/dinamikapendidikan/article/download/19774/10805).

Mua, Marianus Muharli. 2015. "Pelajar Papua Dalam Kuasa Simbolik (Studi Terhadap Reproduksi Kelas Sosial Di SMK Negeri 1 Obaa, Mappi, Papua)." Jurnal Sosiologi Agama 9(2):121-38. doi: 10.14421/jsa.2015.092-07.

Nuraeni, LH, \& Muhammad Syukur. 2018. "Habitus Belajar Siswa Berrestasi Di 
SMA Negeri 12 Makassar.” Jurnal Sosialisasi Pendidikan Sosiologi-FIS UNM 5(2):87-93 (https://ojs.unm.ac.id/sosialisasi/article/view/12239/7242).

Pramika, Depi, Chandra Kurniawan, Widya Agustina, \& Reni Murniati. 2017. "Hubungan Antara Status Sosial Ekonomi Dengan Prestasi Belajar Mahasiswa Program Studi Pendidikan Akuntansi FKIP Universitas PGRI Palembang." Jurnal Neraca: Jurnal Pendidikan Dan Ilmu Ekonomi Akuntansi 1(2):1-15. doi: 10.31851/neraca.v1i2.2207.

Rahayu, Wening P. 2011. "Analisis Intensitas Pendidikan Oleh Orang Tua Dalam Kegiatan Belajar Anak, Status Sosial Ekonomi Orang Tua Terhadap Motivasi Belajar Dan Prestasi Belajar Siswa." Jurnal Pendidikan Dan Pembelajaran (JPP) 18(1):72-80 (https;//journal.um.ac.id/index.php/pendidikan-danpembelajaran/article/view/2759)

Santrock, John W. 2011. Psikologi Pendidikan: “Educational Psychology.” Kedua. Jakarta: Kencana Prenada Media Grup.

Siregar, Mangihut. 2016. "Teori Gado-Gado Pierre-Felix Bourdieu." Jurnal Studi Kultural 1(2):79-82 (https://media.neliti.com/media/publication/223848-teorigado-gado-pierre-felix-bourdieu.pdf).

Siregar, Nina Siti Salmaniah. 2013. "Persepsi Orang Tua Terhadap Pentingnya Pendidikan Bagi Anak." JPPUMA: Jurnal Ilmu Pemerintahan Dan Sosial Politik Universitas Medan Area 1(1):11-27 (https://www.ojs.uma.ac.id/index.php./jppuma/article/view/585).

Swaramarinda, Darma Rika, \& Henry Eryanto. 2013. "Pengaruh Modal Budaya, Tingkat Pendidikan Orang Tua Dan Tingkat Pendapatan Orang Tua Terhadap Prestasi Akademik Pada Mahasiswa Fakultas Ekonomi Universitas Negari Jakarta." Jurnal Pendidikan Ekonomi Dan Bisnis (JPEB) 1(1):39-61. doi: 10.21009/JPEB.001.1.3.

Umanailo, M. Chairul B. 2018. "Mengurai Kekerasan Simbolik Di Sekolah: Sebuah Pemikiran Pierre Bourdieu Tentang Habitus Dalam Pendidikan.” Pp. 1-24 in.

Wempi, Jefri A. 2012. "Teori Produksi Kultural: Sebuah Kajian Pustaka.” ExposureJournal Af Advanced Communication 2(1):364-81 (https://eprints.binus.ac.id/29410/). 